\title{
Vectors and transmission dynamics for Setaria tundra (Filarioidea; Onchocercidae), a parasite of reindeer in Finland Sauli Laaksonen*1, Milla Solismaa ${ }^{\dagger 1}$, Raine Kortet ${ }^{\dagger 2}$, Jussi Kuusela ${ }^{\dagger 1}$ and Antti Oksanen ${ }^{\dagger 1}$
}

\author{
Address: ${ }^{1}$ Fish and Wildlife Health Research Unit, Finnish Food Safety Authority Evira (FINPAR), P.O. Box 517, FI-90101 Oulu, Finland and \\ ${ }^{2}$ University of Oulu, Department of Biology, P.O. Box 3000, FI-90014 Oulu, Finland \\ Email: Sauli Laaksonen* - sauli.laaksonen@evira.fi; Milla Solismaa - milla.solismaa@helsinki.fi; Raine Kortet - raine.kortet@oulu.fi; \\ Jussi Kuusela - jussi.kuusela@te-keskus.fi; Antti Oksanen - antti.oksanen@evira.fi \\ * Corresponding author †Equal contributors
}

Published: 6 January 2009

Parasites \& Vectors 2009, 2:3 doi:10.1186/1756-3305-2-3
Received: 29 September 2008

Accepted: 6 January 2009

This article is available from: http://www.parasitesandvectors.com/content/2/1/3

(c) 2009 Laaksonen et al; licensee BioMed Central Ltd.

This is an Open Access article distributed under the terms of the Creative Commons Attribution License (http://creativecommons.org/licenses/by/2.0), which permits unrestricted use, distribution, and reproduction in any medium, provided the original work is properly cited.

\begin{abstract}
Background: Recent studies have revealed expansion by an array of Filarioid nematodes' into the northern boreal region of Finland. The vector-borne nematode, Setaria tundra, caused a serious disease outbreak in the Finnish reindeer population in 2003-05. The main aim of this study was to understand the outbreak dynamics and the rapid expansion of $S$. tundra in the sub arctic. We describe the vectors of $S$. tundra, and its development in vectors, for the first time. Finally we discuss the results in the context of the host-parasite ecology of S. tundra in Finland
\end{abstract}

Results: Development of $S$. tundra to the infective stage occurs in mosquitoes, (genera Aedes and Anopheles). We consider Aedes spp. the most important vectors. The prevalence of $S$. tundra naturally infected mosquitoes from Finland varied from 0.5 to $2.5 \%$. The rate of development in mosquitoes was temperature-dependent. Infective larvae were present approximately I 4 days after a blood meal in mosquitoes maintained at room temperature (mean $2 \mathrm{I} \mathrm{C}$ ), but did not develop in mosquitoes maintained outside for 22 days at a mean temperature of $14.1 \mathrm{C}$. The third-stage (infective) larvae were elongated (mean length I4II $\mu \mathrm{m}$ (SD 207), and width $28 \mu \mathrm{m}$ (SD 2)). The anterior end was blunt, and bore two liplike structures, the posterior end slight tapering with a prominent terminal papilla. Infective larvae were distributed anteriorly in the insect's body, the highest abundance being 70 larvae in one mosquito. A questionnaire survey revealed that the peak activity of Culicidae in the reindeer herding areas of Finland was from the middle of June to the end of July and that warm summer weather was associated with reindeer flocking behaviour on mosquito-rich wetlands.

Conclusion: In the present work, S. tundra vectors and larval development were identified and described for the first time. Aedes spp. mosquitoes likely serve as the most important and competent vectors for $S$. tundra in Finland. Warm summers apparently promote transmission and genesis of disease outbreaks by favouring the development of $S$. tundra in its mosquito vectors, by improving the development and longevity of mosquitoes, and finally by forcing the reindeer to flock on mosquito rich wetlands. Thus we predict that global climate change has the potential to promote the further emergence of Filarioid nematodes and the disease caused by them in subarctic regions. 


\section{Background}

There is recent evidence documenting the range expansion of parasites of domestic and free-ranging ungulates to subarctic areas including, in Finland, an array of vectorborne Filarioid nematodes and the diseases associated with them [1-3]. These findings are not surprising, since the potential impacts of global warming are predicted to include shifts in the spatial-temporal distribution of disease vectors, and hence the transmission dynamics of vector-borne diseases [4]. There is still a lack of basic knowledge, however, about how insect populations, their vector competence, and parasite-host ecology respond to these changes.

Setaria tundra (Filarioidea: Onchocercidae) was the causative agent of severe outbreaks of peritonitis in semidomestic reindeer (Rangifer tarandus tarandus) in Finland in 1973 and in 2003-05, and in moose (European elk, Alces alces) in Lapland in 1989 [1]. The most recent outbreak started in 2003 in the southern part of the Finnish reindeer herding area and the focus of the outbreak has moved northwards approximately $100 \mathrm{~km}$ each year.

In this latest outbreak the prevalence and level of infection were very high in the calves, and caused substantial economic losses to the reindeer herders. Adult reindeer were suggested as the main source of infection for the calves $[1,2]$, together with wild forest reindeer (Rangifer tarandus fennicus) and roe deer (Capreolus capreolus) [1,2].

The genus Setaria includes 43 species that are found in the abdominal cavities of artiodactyls. All these species produce microfilariae ( $\mathrm{mf}$ ) which are present in host blood where they are available to the arthropod vectors. The $\mathrm{mf}$ are taken up in the blood meal of the vector where they develop into the infective third larval stage. When the vector feeds again, the larvae break out and enter the tissue of the definitive host [5].

The life cycle of $S$. tundra in the Northern Europe is poorly understood. In California, the mosquito Aedes sierrensis serves as a vector for a related species, Setaria yehi, which parasitizes white-tailed deer (Odocoileus virginianus). In this host-parasite system, transmission is facilitated by the peak appearance of mosquitoes following the fawning season of the deer [6]. Other known insect vectors for Setaria spp are other Aedes spp. [7,8], Anopheles spp. [912], and horn flies, Haematobia irritans [13] and H. stimulans [13-15].

To date there is only scant information about the transmission of $S$. tundra other than the recent studies in Finland on the peritonitis outbreak in reindeer and $\mathrm{mf}$ burden in cervids $[1,2]$. The assumption that $S$. tundra is transmitted by haematophagous vectors is supported by the seasonal midsummer peak in Setaria microfilaria (Smf) density in reindeer [2], and by the well known attacks on herds of caribou/reindeer in the summer by massive swarms of blood-feeding insects [16].

The aims of the present study were: 1) to identify significant vectors for $S$. tundra in Finland; 2) to describe larval development in these vectors; and 3) to use this knowledge to explore basic features of parasite transmission, including outbreak dynamics and the rapid geographic expansion of S. tundra in Finland.

\section{Results}

Setaria tundra larvae in wild haematophagous insects

Data for $S$. tundra occurrence in wild-netted Aedes spp. mosquitoes and in sympatric reindeer are presented in Table 1. Larvae of the parasite in different developmental stages ("sausages", $\mathrm{L}_{2}$ and $\mathrm{L}_{3}$ ) were detected in Aedes communis, A. punctor, A. hexodontus, A. excrucians. Oviposition status numbers was determined for 166 mosquitoes (Aedes spp.) dissected, of which 64 (38.5\%) had laid eggs one or more times. All captured blackflies (Simulidae), biting midges (Culicoidea) and hornflies (Hydrotea spp.) were negative for developing $S$. tundra larvae, although Smf (Figure 1) were detected (1-800/insect) in the guts of these insects after a blood meal.

All hibernating Culiseta and Anopheles spp. mosquitoes were nulliparous and none contained $S$. tundra larvae.

\section{The development of S. tundra in mosquitoes}

Trial I: outdoor conditions

Species of Aedes included in the study were: Aedes communis $(\mathrm{n}=14)$; A. hexodontus $(\mathrm{n}=8) ;$ A. punctor $(\mathrm{n}=4)$; and other unidentified Aedes spp. $(\mathrm{n}=9)$. All 35 mosquitoes were nulliparous. The prevalence of $S$. tundra immediately following the blood meal was 57\%, and the number of developing larvae in infected individuals varied from 1 to 25 (mean 7, SD 5.4). On day 1 after the blood meal, mf were already unsheathed (mean length $255.8 \mu \mathrm{m}, \mathrm{SD}$ 14.2, mean width $6 \mu \mathrm{m}, \mathrm{SD} 0.97)$, and were still in the abdomen. During day 2 the larvae migrated into the tho$\operatorname{rax}(\mathrm{n}=10$ mosquitoes). Larvae reached the sausage stage (late first-stage, mean length $122.5 \mu \mathrm{m}$, SD 14.4, mean width $16.6 \mu \mathrm{m}, \mathrm{SD} 2.2$ ) on days 6 to 9 after the blood meal and remained in the late first-stage or early second stage after day 16 (mean length $185.6 \mu \mathrm{m}$, SD 18.6, mean width $\mu \mathrm{m}$ 29.9, SD 6.5). No third-stage infective larvae were observed up to day 22 after the blood meal, when the trial ended.

\section{Trial II: laboratory conditions}

Of the mosquitoes included in this trial, 97 belonged to genus Aedes and 7 to genus Anopheles, and all were nulliparous. 


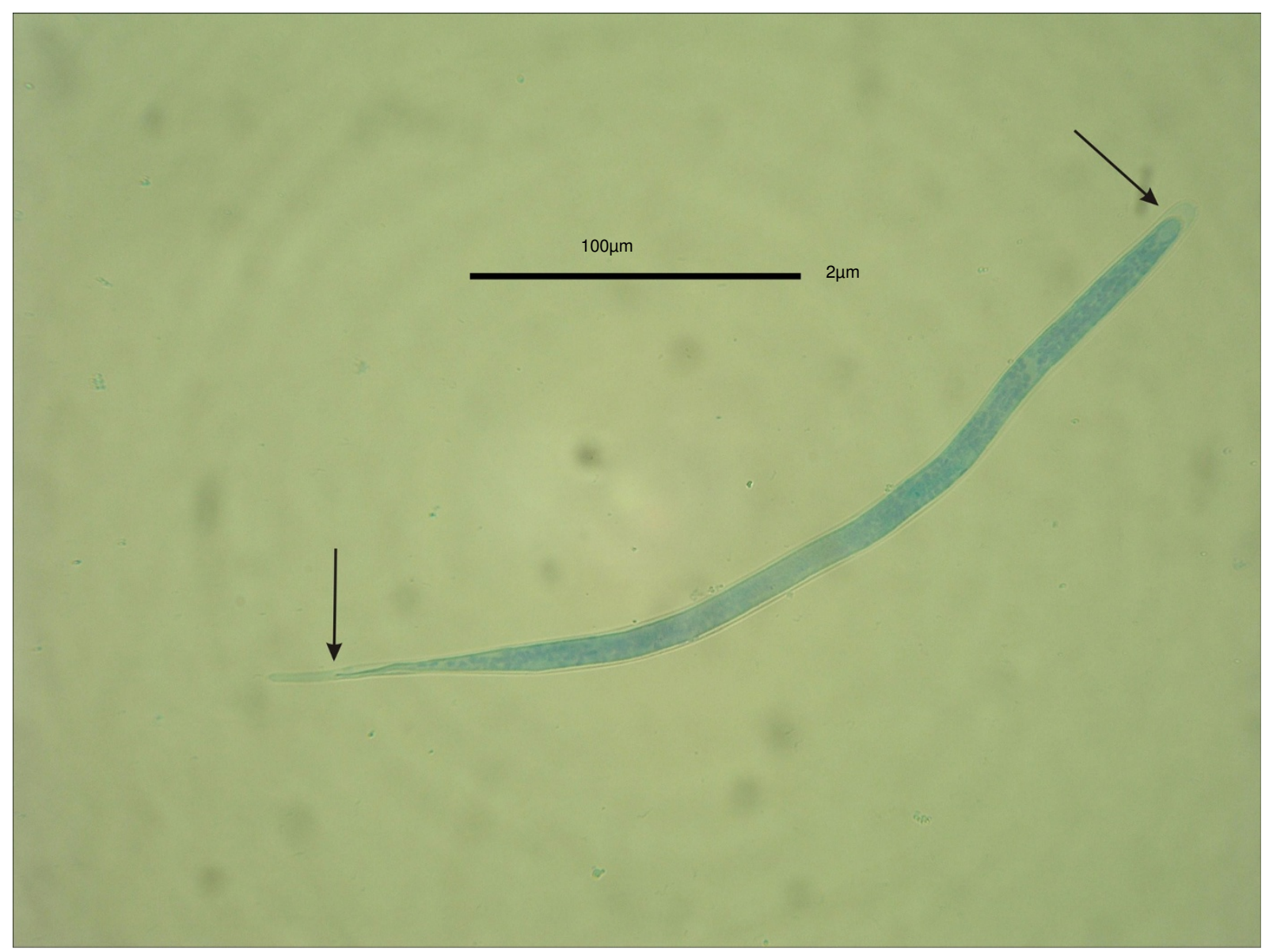

\section{Figure I}

Sheated (arrows) S. tundra microfilaria in the gut of Aedes sp. immediately after blood meal.

Following the blood meal, developing S. tundra larvae were observed in 40 of the Aedes spp. mosquitoes (prevalence $41 \%$ ) and individual mosquitoes harboured 1 to 51 larvae (mean 8, SD 10.7). The development of $S$. tundra larvae in Aedes mosquitoes is presented in Table 2 and Figure 2. During day 1 , the larvae unsheathed and migrated to the thoracic muscles. Larvae reached the sausage stage after days 4 to 6 , and at this stage had a short, distinct tail and, in the more developed larvae, the mouth, oesophagus and intestine were quite distinct. After days 9 to 10 the larvae were slender and had approximately doubled in length. In these second-stage larvae, the anal plug was visible, but the tail had been lost during the first moult. At this stage, the lumen of the intestine and oesophagus were distinct. Finally, approximately two weeks after the blood meal, and following the second moult, infective elongated

Table I: Recovery of Setaria tundra larvae from Aedes spp. mosquitoes and of microfilariae from reindeer in six locations in Finland, summer 2004.

\begin{tabular}{|c|c|c|c|c|c|c|}
\hline Place & Diss. mosq. (captured) & Inf. mosq. & Prevalence (\%) & No of S. tundra larvae,(range) & smf-prev in reindeer & Collection time \\
\hline Perho & $200(443)$ & 1 & 0,5 & 8 & $15 \% \mid$ & July $22^{\text {th }}$ \\
\hline Kuhmo & | 48 (I48) & I & 0,7 & 5 & $36 \% 1$ & July 19th \\
\hline Kuusamo & $210(2061)$ & I & 0,5 & 3 & $61 \% 2$ & July $3^{\text {th }}-$ August $28^{\text {th }}$ \\
\hline Sodankylä & $200(254)$ & 4 & 2 & $3(2-4)$ & $10 \% 2$ & July $29^{\text {th }}$ \\
\hline Kaamanen & $200(286)$ & 0 & 0 & - & $0 \% 2$ & July $28^{\text {th }}$ \\
\hline Oulu Zoo & $200(1680)$ & 5 & 2,5 & $2(I-3)$ & $100 \% 2$ & June $10^{\text {th }}-$ August $20^{\text {th }}$ \\
\hline Tot & 958 (4429) & 12 & 1.2 & & & \\
\hline
\end{tabular}

IWild forest reindeer, ${ }^{2}$ Reindeer 


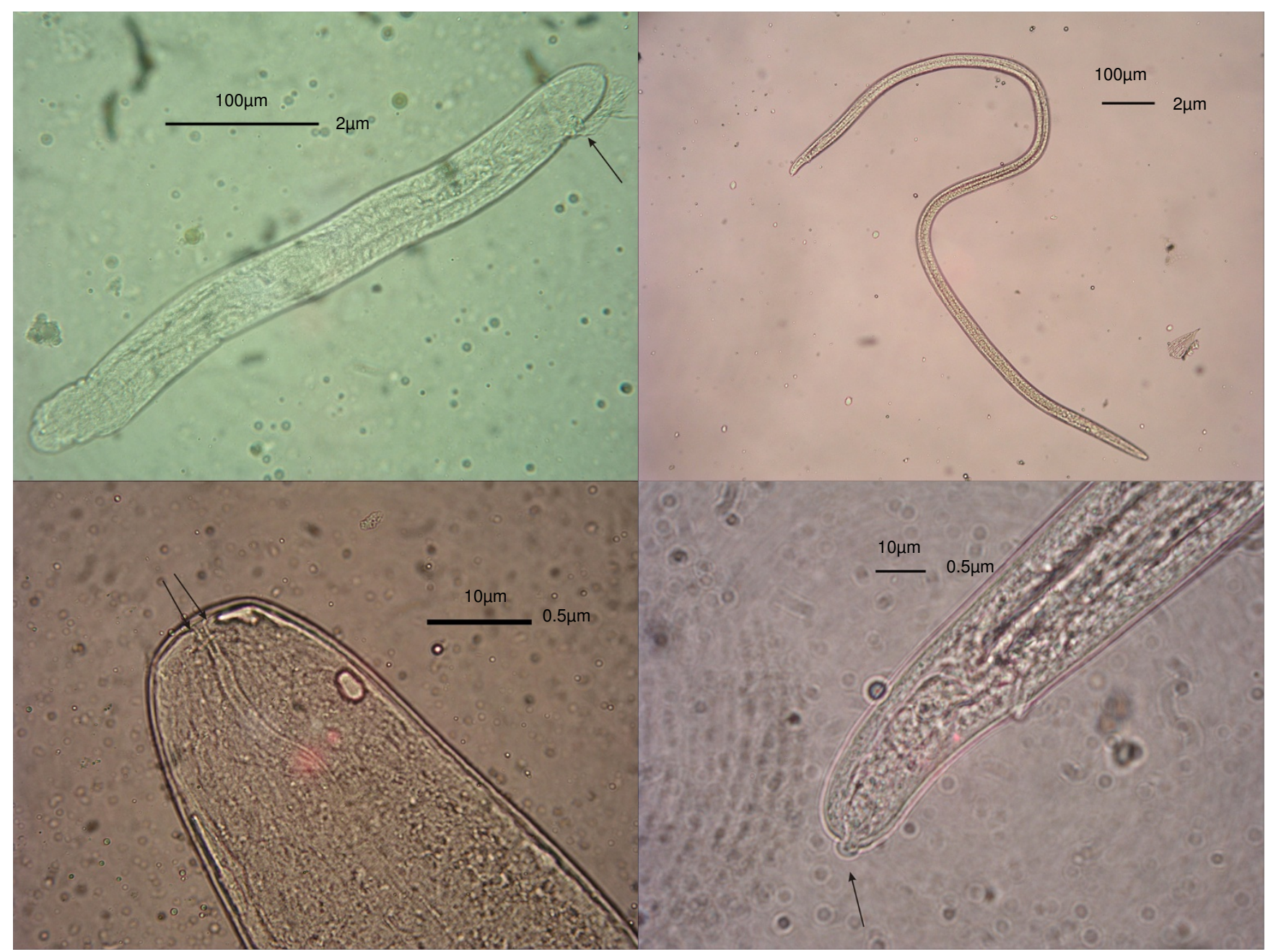

\section{Figure 2}

The development of $S$. tundra larvae in Aedes sp. mosquito. a. $2^{\text {nd }}$ stage larvae with visible anal plug (arrow). b. Elongated $3^{\text {rd }}$ stage larvae: The identification details of $S$. tundra infective $3^{\text {rd }}$ stage larvae in.; c. Blunt anterior end with two liplike stuctures (arrows). d. Tapering posterior end with prominent terminal (knoblike) papilla (arrow).

third-stage larvae were present. The anterior ends of these larvae were blunt, slightly tapering and bore two liplike structures, the posterior ends were slightly tapering from the anus with a prominent terminal (knoblike) papilla. The intestines were broad, round, and tubular and showed much variation. The cuticule had transverse striations.

Approximately $51 \%$ of the infective larvae were located in the thorax, $31 \%$ in the head or proboscis and $18 \%$ in the abdomen. Measurements of older S. tundra larvae in five Aedes specimens are presented in Table 3.

Six of the seven Anopheles spp. collected contained S. tundra larvae. Three of the infected mosquitoes examined 67 days after the blood meal contained developing larvae (mean burden 2.7 (SD 1.2); mean length $253 \mu \mathrm{m}$ (SD
60); mean width $29.3 \mu \mathrm{m}$ (SD 5.5)). At each examination at days 9-10, 11-13 and 21-22 after the blood meal a single Anopheles mosquito was found infected and 4, 3 and 7 larvae, respectively, were recovered. Measurements of these larvae were: mean length $440 \mu \mathrm{m}$ (SD 95.3), 231.5 $\mu \mathrm{m}$ (SD 9.2) and $1423 \mu \mathrm{m}$ (SD 68.7); and mean width $36.6 \mu \mathrm{m}$ (SD 0.97), $32.6 \mu \mathrm{m}$ (SD 5.6) and $29.3 \mu \mathrm{m}$ (SD $2.1)$, respectively.

Melanisation was recognized in 11 mosquitoes during the developmental studies. Melanised larvae were mostly microfilariae in the abdomen but more-developed and melanised larvae were also observed in the thorax.

\section{PCR studies}

The $680 \mathrm{bp}$ mtDNA sequence to the sequences from all 6 $S$. tundra larvae examined were identical to those from 
Table 2: The development of S. tundra larvae in laboratory insectary conditions $\left(21^{\circ} \mathrm{C}\right.$, SD 2.8 , relative humidity $65 \%$, SDI 2.4$)$ in Aedes mosquitoes.

\begin{tabular}{|c|c|c|c|c|c|c|c|c|c|}
\hline $\begin{array}{l}\text { Days after } \\
\text { blood meal }\end{array}$ & 1 & $2-3$ & $4-6$ & $7-8$ & $9-10$ & $11-13$ & $14-16$ & $17-20$ & $21-22$ \\
\hline No & 2 & 2 & 10 & 9 & 4 & 3 & 2 & 3 & 5 \\
\hline $\begin{array}{l}\text { Mean larvae } \\
\text { (SD) } \\
\text { Range }\end{array}$ & $\begin{array}{l}1 \\
-\end{array}$ & $\begin{array}{c}1.5 \\
(0.5) \\
1-2\end{array}$ & $\begin{array}{c}2.8 \\
(1.9) \\
1-7\end{array}$ & $\begin{array}{c}3.3 \\
(1.2) \\
1-5\end{array}$ & $\begin{array}{c}11 \\
(8.4) \\
3-24\end{array}$ & $\begin{array}{c}8.4 \\
(6.5) \\
3-21\end{array}$ & $\begin{array}{c}5,5 \\
(2.5) \\
3-8\end{array}$ & $\begin{array}{c}28 \\
(18) \\
8-5 \mid\end{array}$ & $\begin{array}{c}17(11,2) \\
6-34\end{array}$ \\
\hline $\begin{array}{l}\text { Mean length } \\
\text { (SD) } \\
\text { Range }\end{array}$ & $\begin{array}{c}266 \\
(9.3) \\
257-275\end{array}$ & $\begin{array}{c}194 \\
(19) \\
176-220\end{array}$ & $\begin{array}{c}191 \\
(42) \\
132-330\end{array}$ & $\begin{array}{c}295 \\
(60) \\
165-385\end{array}$ & $\begin{array}{c}45 \mid \\
(99) \\
198-803\end{array}$ & $\begin{array}{c}885 \\
(388) \\
165-1210\end{array}$ & $\begin{array}{c}1687 \\
(104) \\
1540-1760\end{array}$ & $\begin{array}{c}1333 \\
(180) \\
935-1595\end{array}$ & $\begin{array}{c}1504 \\
(155) \\
1100-1760\end{array}$ \\
\hline $\begin{array}{l}\text { Mean width } \\
\text { (SD) } \\
\text { Range }\end{array}$ & $\begin{array}{c}7.9 \\
(1.1) \\
6.75-9\end{array}$ & $\begin{array}{c}25 \\
(4.9) \\
20-32\end{array}$ & $\begin{array}{c}23 \\
(4.4) \\
14-32\end{array}$ & $\begin{array}{c}31 \\
(5) \\
18-36\end{array}$ & $\begin{array}{c}35 \\
(2.5) \\
32-41\end{array}$ & $\begin{array}{c}38 \\
(6.2) \\
23-45\end{array}$ & $\begin{array}{c}29 \\
(2) \\
27-32\end{array}$ & $\begin{array}{c}27,4 \\
(1) \\
27-32\end{array}$ & $\begin{array}{c}29 \\
(2,3) \\
27-36\end{array}$ \\
\hline Development site & thorax & Thorax & thorax & thorax & thorax & thorax & thorax, abd, head & $\begin{array}{l}\text { thorax, abd, head, } \\
\text { prob, palps }\end{array}$ & $\begin{array}{c}\text { Thorax, abd, head, } \\
\text { prob, palps }\end{array}$ \\
\hline Larvae tot. & 2 & 3 & 28 & 26 & 43 & 30 & 11 & 83 & 84 \\
\hline
\end{tabular}

adult $S$. tundra parasitizing reindeer in northern Finland (GenBank DQ097309) [1]. The partial 18S ribosomal RNA gene sequences of the $S$. tundra larvae were also identical to those from $S$. tundra microfilaria from the blood of these reindeer (GenBank EF081341) [2].

\section{Questionnaire survey}

All Chiefs of District of the 56 reindeer herding cooperatives in the Finnish reindeer herding area (Figure 3), responded to the questionnaire. The results indicate that overall harassment by flying mosquitoes during the summers of $-2003,-2004$ and -2005 was less severe than the average (for 2003, 69\% of respondents, for 2004, 77\%, and for $2005,46 \%$, respectively) or about average (29\%, $22 \%$ and $52 \%$ or respondents, respectively) in the whole reindeer herding area. Respondents also reported that the peak activity of Culicidae occurs from mid-June to the end of July (Figure 4). Moreover, the mosquito feeding activity on reindeer was reported to be the highest in the evenings (37\% of respondents) or at dawn $(18 \%)$ and at dusk $(10 \%)$ or if warm enough, at night $(18 \%)$. According to $86 \%$ of the Chiefs, weather conditions and insect harassment alter reindeer behaviour so that during warm weather reindeer flock mostly in wetlands, swamps and riversides, and sometimes in forests (18\% of respondents) in fells $(14 \%)$ and different kinds of open expanses $(16 \%)$. In cool summers, flocking behaviour is diminished. In areas of high $S$. tundra prevalence some Chiefs (11 of 56) reported on their own initiative that the prevalence of disease associated with $S$. tundra (peritonitis detected at slaughter) in reindeer herds varied depending on the site of herd's summer pasture.

\section{Discussion}

This study has provided evidence that mosquitoes, particularly Aedes spp. and to a lesser extent Anopheles spp., have an important role in the transmission of Setaria tundra in the reindeer herding areas of Finland. The study has also provided information on the morphological changes in $S$. tundra larvae developing in mosquitoes, and on the distribution of these larvae in the vectors. It has also demonstrated that at a mean temperature of $21 \mathrm{C}$ larvae develop to the infective third stage in approximately two weeks, while at a mean temperature of $14.1 \mathrm{C}$, development is not completed. Finally, questionnaire results suggest a

Table 3: . Details of S. tundra larvae obtained from five Aedes mosquitoes.

\begin{tabular}{|c|c|c|c|c|c|}
\hline Species & Days after blood meal & Larvae (n) & Mean length, (SD), range & Mean width, SD, range & Development site $(n)$ \\
\hline Aedes sp. & I & 2 & broken & $\begin{array}{l}38.25 \mu \mathrm{m} \\
36-40.5\end{array}$ & thorax \\
\hline Aedes sp. & $2-3$ & 15 & $1634 \mu \mathrm{m},(132), 1375-1870$ & $\begin{array}{l}32.7 \mu \mathrm{m} \\
(2.5), 31.5-40.5\end{array}$ & $\begin{array}{l}\text { thorax (I3) } \\
\text { proboscis (I) } \\
\text { abdomen (I) }\end{array}$ \\
\hline Aedes sp. & $2-3$ & 70 & $807 \mu \mathrm{m},(27 \mathrm{I}), 418-1210$ & $37.6,(2.2), 36-40.5$ & $\begin{array}{l}\text { thorax (69) } \\
\text { abdomen (1) }\end{array}$ \\
\hline Aedes sp. & 4-6 & 4 & Broken & $45 \mu \mathrm{m}$ & thorax \\
\hline Aedes sp. & $7-8$ & 20 & III5 $\mu \mathrm{m},(277.8), 855-1500$ & $50.6 \mu \mathrm{m},(5.5), 45-59.4$ & thorax \\
\hline
\end{tabular}

The larvae were excluded from the development measurements because they were considered older, originating from previous blood meals. 


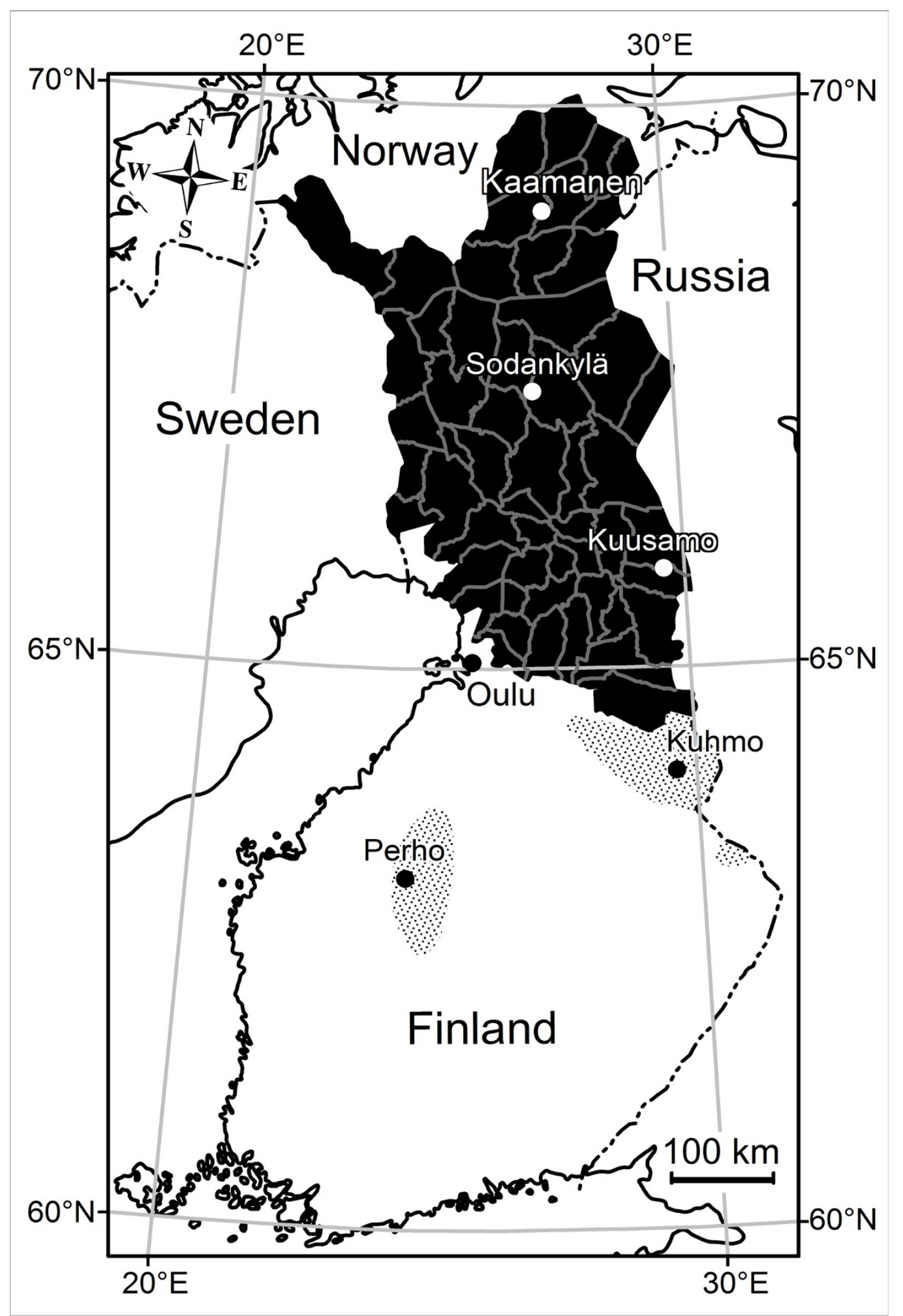

Figure 3

Finnish reindeer herding area (black) divided in $\mathbf{5 6}$ reindeer herding cooperatives and two wild forest reindeer populations (shaded). The foci of S. tundra associated disease [I] and S. tundra microfilaremia in reindeer blood [2] was in 2003 in the area I, and moved northwards during next two years into the area 3, while the area 4 remained free of infection. 


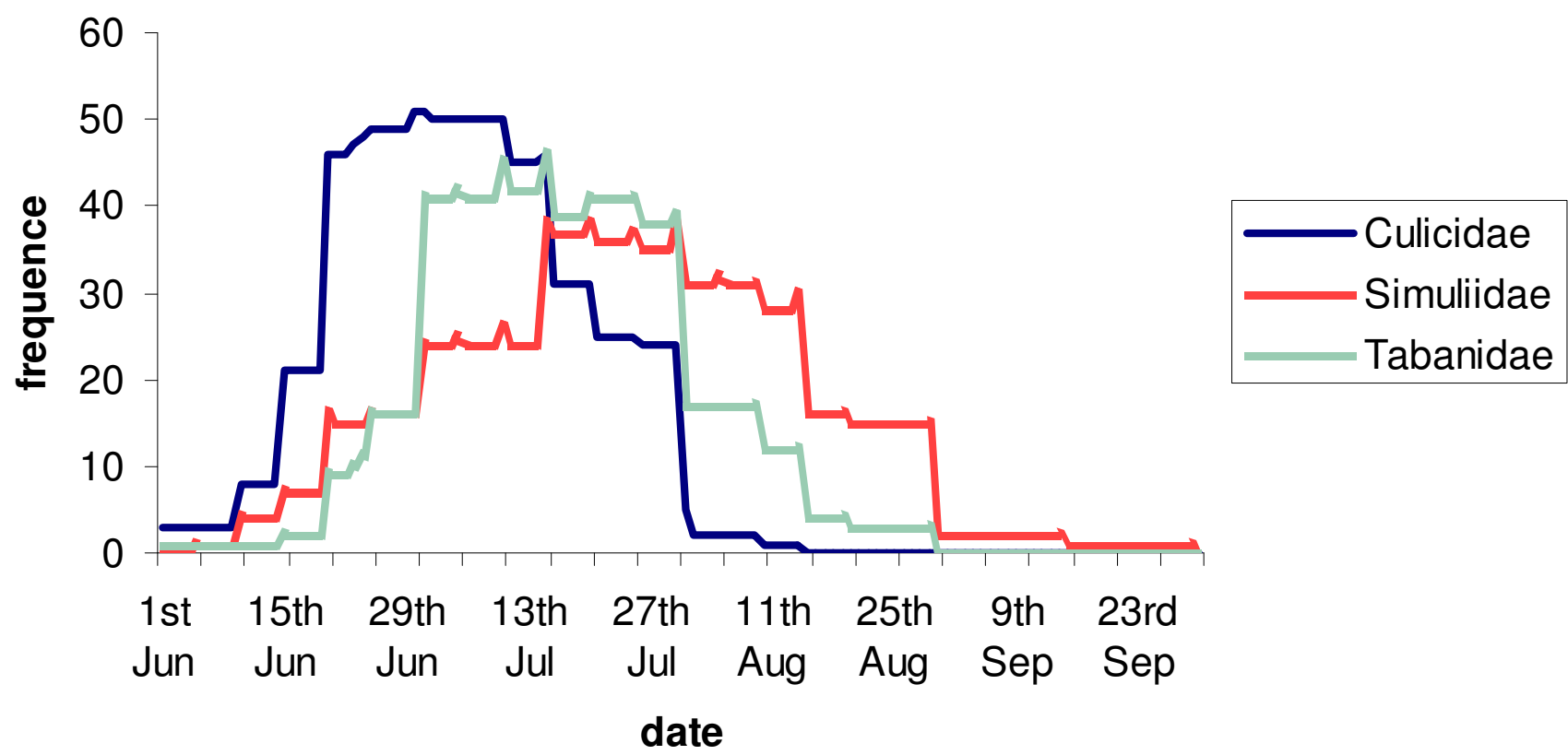

Figure 4

The frequency and activity patterns of räkkä-insects (Culicidae, Simuliidae and Tabanidae) in the summer months in Lapland (data from the questionnaire).

linkage between levels of vector activity in the field and the transmission of $S$. tundra among reindeer.

The morphological changes, distributions and development rates of $S$. tundra in mosquitoes, observed in the present study are similar to those for other Setaria spp. described previously $[5,9,11,17,18]$.

In the present study there was considerable variation in the morphology of the developing larval stages, as observed earlier for species of the Filarioidea developing in different vectors [19]. These variations might make the identification of the larvae difficult other than at the family level, and illustrate the role of PCR-based methods for species identification.

The vast majority of mosquitoes active in midsummer in Finland are species of Aedes [20]. Although Anopheles mosquitoes are also present, and can serve as vectors for $S$. tun$d r a$, their epidemiologic significance in Finland is likely limited because of their life cycle parameters and low numbers compared to Aedes spp. [20]. The role of Anopheles mosquitoes may be more important in more temperate areas or may increase in Finland during climate change. Our results suggest that $S$. tundra is not a very vector-specific parasite, and this may enhance its ability to expand its geographic range. Also, adult female Aedes spp. are vigorous round-the-clock feeders that can be infected with many infective S. tundra larvae (up to 70 in the present study). This high larval abundance may, however, decrease vector efficiency and increase vector mortality.

The transmission of $S$. tundra is highly dependent on the life span of the female mosquitoes, with survival of adult mosquitoes depending in part on both temperature and humidity [21]. There is unfortunately no information on the longevity of mosquito populations in Finland, although in the present study adult Aedes spp. survived approximately four weeks in a laboratory insectary at room temperature. In the present study, older females were a considerable part of the "wild" mosquito population. It is interesting that although the $S$. tundra outbreak in Sweden in 1973 was associated with the appearance of especially large numbers of mosquitoes [22], the longevity of the mosquitoes is also important.

The peak period of $S$. tundra microfilaremia in reindeer is from mid June to the end of August [2], which data from the questionnaire suggest co-incides with the peak activity of mosquitoes. Some estimates suggest that reindeer can be exposed to attacks of approximately 8000 mosquitoes/ hour during the räkkä-time (the appearance of mass insect harassment) [23]. These peaks in microfilaremia and insect abundance and contact with reindeer occur just after the calving season, when the reindeer shed their winter hair leaving their skin relatively exposed to the attacks 
of mosquitoes. This synchrony likely promotes the transmission of $S$. tundra from adult carriers to calves [2].

In highly endemic areas, the prevalence of Filarioid infection rarely exceeds $1 \%$ of the total mosquito population [24]. In this study, S. tundra prevalence in different mosquito populations in endemic areas was $0.5-2.5 \%$, the highest prevalence being around the experimental zoo, an urban park-like environment, on the outskirts of Oulu city.

In the present study, according to the questionnaire results, warm summers were associated with hundreds of reindeer flocking in dense herds in mosquito-rich wetlands. This behaviour may be explained by the availability of drinking water and fresh food plants or the benefits of the habitat for thermoregulation [16]. In these areas the microclimate is favourable for mosquitoes and it is possible that in these kinds of highly endemic areas, the prevalence and abundance of $S$. tundra in mosquitoes is very high. In a previous study in upper Lapland, the ancient destination of reindeer summer migration, neither peritonitis [1] nor $\mathrm{mf}[2]$, were found in reindeer, and there mosquitoes infected with $S$. tundra were not found. These observations suggest that the migrations of reindeer and the characteristics of reindeer pastures can affect the transmission dynamics of $S$. tundra. This may help explain the numerous discoveries by reindeer herders of great variation in S. tundra levels in reindeer herds originating from different summer pastures. In Uzbekistan, the highest prevalence of $S$. labiatopapillosa in cattle was found in irrigated, marshy and river catchment areas [25]. It is also important to note that wetlands constitute about 30 to $40 \%$ of the total land area of the S. tundra outbreak area but only about $12 \%$ of upper Lapland, [26] which is believed to be free of $S$. tundra $[1,2]$.

\section{Conclusion}

The present study has revealed the lack of basic knowledge of filarial larvae in their vectors in northern latitudes. In Finland, mosquitoes, especially Aedes spp., are efficient and likely the most important vectors of $S$. tundra. A key factor promoting the transmission of this parasite is warm ambient summer temperature. Within limits, this warmth improves mosquitoes' development, reproduction, longevity and feeding habits, as well as the larval development of $S$. tundra. Warm summers, which may become warmer as a consequence of climate change, also force the reindeer to flock and stay on mosquito-rich wetlands, behaviour which might increase the infection pressure. It is likely that climate change [27] favours the northward expansion of Filarioid nematodes, which might then become an even greater threat to arctic ungulate populations. The current study has provided baseline information that will improve understanding of the ecology and dynamics of $S$. tundra and of disease outbreaks associated with the parasite. The information could also be useful in predicting and preventing these outbreaks.

\section{Methods \\ Identification of significant vectors for S. tundra}

To estimate the prevalence of $S$. tundra larvae in arthropod populations in different $S$. tundra endemic areas, insect samples were collected from various locations (Figure 3 ). The samples were taken by netting insects attacking the experimental reindeer or humans on pastures with high reindeer density. Simultaneously S. tundra infection rates in the reindeer were monitored from blood samples (see [2]). Individual insects were randomly selected from the samples and examined for $S$. tundra larvae. Collected and examined mosquitoes are presented in Table 1. Other examined insects and collection times were: Perho; 13 black flies (July 22th), Kuhmo; 111 black flies and 6 Hydrotea spp. (July $19^{\text {th }}$ ), Kuusamo; 192 black flies and 88 Hydrotea spp. (July $3^{\text {th }}-$ August $28^{\text {th }}$ ), Sodankylä; 305 black flies (July 29th), Kaamanen; 129 black flies (July $28^{\text {th }}$ ), Oulu University Experimental Zoo; 55 black flies, 1267 biting midges and 119 Hydrotea spp. (June $10^{\text {th }}-$ August 20 ${ }^{\text {th }}$ ) (Figure 3).

To examine the possibility of $S$. tundra larvae surviving in mosquitoes over the winter, hibernating and newly emerged Anopheles spp. $(\mathrm{n}=25)$ and Culiseta spp. $(\mathrm{n}=95$, Culiseta alaskaensis 34, Culiseta bergrothi 61) mosquitoes were collected between April 24th and May22 ${ }^{\text {nd }}, 2005$ from winter caves in pastures in Kuusamo grazed by reindeer with high $S$. tundra prevalence $[1,2]$.

Field-netted insects were killed using ether and stored frozen before dissection. Haematophagous insects were identified to genus and when possible to species. During dissection, the mosquitoes were divided into three parts (head, thorax and abdomen) which were examined using a stereomicroscope and mounted separately in a drop of Aedes-ringer [28] on a slide. A coverslip was then added and the specimen examined under a compound microscope at $40 \times$. Oviposition status of the mosquitoes was determined according to Detinova [29]. All developing larvae found in the study were photographed and their length and width measured. The specimens were identified to family according to Bain and Chabaud [30].

\section{PCR studies}

Six larvae were collected from six mosquitoes: one from a wild Aedes mosquito from Kuusamo and five from Aedes mosquitoes from the second development trial. Mosquitoes were digested in $10 \mu \mathrm{l}$ of a solution containing $0,45 \%$ Tween 20 (Merck, Germany) and 0.45\% Igepal CA-630 (Sigma-Aldrich, Germany), PCR-buffer (10 mM Tris-HCl, $1.5 \mathrm{mM} \mathrm{MgCl} 2,50 \mathrm{mM} \mathrm{KCl}$ and $0.1 \%$ Triton X-100) 
(Finnzymes, Finland) and $500 \mu \mathrm{g} / \mathrm{ml}$ Proteinase $\mathrm{K}$ (Finnzymes, Finland). Samples were incubated at $65^{\circ} \mathrm{C}$ for $30 \mathrm{~min}$ followed by $10 \mathrm{~min}$ at $95^{\circ} \mathrm{C}$. For one PCR reaction, 2-5 $\mu \mathrm{l}$ of digestion solution was used. The presence of $S$. tundra was demonstrated by comparing mitochondrial DNA sequences with all known sequences of $S$. tun$d r a$ as well as other Filarioidea species. The primers StCoI $616 \mathrm{~L}$ and StCoI $1321 \mathrm{H}$ were used to amplify part of CoxI gene. The specific $S$. tundra primers and PCR conditions were as previously described $[1,2]$. Because many sequences for $18 \mathrm{~S}$ rRNA genes of different Filarioidea species are available in GenBank, we decided to amplify also that gene. Two new $18 \mathrm{~S}$ rRNA gene primers had been developed earlier for the identification of microfilariae in cervid blood [2]. All known suitable 18S rRNA sequences of Filarioidea in GenBank was used as templates. The sequences of these primers are: 18S_F2 5' CCGCGGTAATTCCAGCTC and 18S_R1 5' CCTACGGAAACCTTGTTACGAC. These primers allow the amplification of partial $18 \mathrm{~S}$ rRNA genes (1.2 kp).

\section{Larval development of S. tundra in mosquitoes}

Two trials exploring the development of $S$. tundra larvae in mosquitoes were conducted at the Oulu University Experimental Zoo. The zoo is located on the university campus within the city of Oulu, but outside the outside the reindeer herding area, and there are no contacts between the zoo reindeer and other reindeer or roe deer. The eight reindeer in the zoo, which served as the source of the blood meal for the mosquitoes at the start of the trials, were naturally infected with $S$. tundra and their Smf densities in the blood were continuously monitored (see [2]). Mosquitoes which were seen to feed on the reindeer were captured by a paper cup pooter, upholstered with cotton wool, on the vertical surfaces of the reindeer feeding shelter.

\section{Trial I, outdoor conditions}

Mosquitoes $(\mathrm{n}=34)$ were trapped on June $17^{\text {th }}$ and $18^{\text {th }}$, 2004. Mean Smf density in the blood from the zoo reindeer was $1007 / \mathrm{ml}$ (SD 661, range 109-1800). The trapped mosquitoes were individually maintained outdoors (average daily mean temperature $14.1{ }^{\circ} \mathrm{C}$, SD 2.6 and relative humidity 70.1\%, SD 6.6) in small plastic vials permeable to air. The mosquitoes were provided with daily $10 \%$ glucose solution and water provided ad lib. The liquids were served via soaked blotting paper and cotton wool which were daily renewed.

\section{Trial II, laboratory conditions}

The mosquitoes ( $\mathrm{n}=104,97$ Aedes. spp, and 7 Anopheles spp.) were netted at the zoo on August $3^{\text {rd }}, 2004$. On this day, the mean Smf density in the blood of the reindeer varied from 0 to 2900/ml (mean 1183, SD 1090). The trapped mosquitoes were maintained under constant insectary conditions in the laboratory $\left(21^{\circ} \mathrm{C}\right.$, SD 2.8 , relative humidity $65 \%$, SD 12.4) and fed as in trial I.

Mosquitoes were periodically killed in freezer $\left(-80^{\circ} \mathrm{C}, 30\right.$ s.) before examination. For data treatment, they were divided into categories $1,2-3,4-6,7-8,9-10,11-13$, 14-16, 17-20 and 21-22 days after blood meal.

Five of the Aedes mosquitoes trapped contained S. tundra in advanced stages of development, indicating that they had fed on infected reindeer some days before capture. These were excluded from the developmental studies, together with the seven infected Anopheles spp. mosquitoes captured.

\section{Questionnaire survey}

To assess the timing and severity of the mass appearance of blood sucking insects during the $S$. tundra outbreak in the summers 2003, 2004 and 2005, and also the behavioural response of reindeer to the resulting insect harassment and to the prevailing weather conditions, in 2006 a questionnaire was administered to all Chiefs of District of the 56 reindeer herding cooperatives in the Finnish reindeer herding area. Respondents were also asked about any experiences concerning outbreaks of disease in the area associated with $S$. tundra. The questionnaire was mailed to participants, and in some cases completed by telephone.

\section{Competing interests}

The authors declare that they have no competing interests.

\section{Authors' contributions}

SL conceived and designed the study and participated in the realization of the study and trials. SL also drafted the manuscript. MS participated in the design and performed the arthropod dissection and larvae extraction. RK participated in the manuscript writing. JK carried out the molecular genetic studies and drafted the manuscript. SN and SS carried out the morphological studies and drafted the manuscript. AO participated in the design and coordination of the study and was active in writing. All authors involved in the analysis of the data, gave their views, read and approved the final manuscript.

\section{Acknowledgements}

All the animal handling procedures for this work were accepted by the Experimental Animal Committee, the University of Oulu (license no. 030/ 04). The authors thank Ministry of Agriculture and Forestry (MAKERA) for funding the Reindeer Health Care Program, which constituted the basis of this study. RK was funded by University of Oulu during the preparation of the manuscript. We thank the personnel of the Oulu University Experimental Zoo and the laboratory personnel of Evira in Oulu, for assistance, and and Juhani Itämies from the University of Oulu who helped us in the arthropod recognition, and Arlo Pelegrin who gave helpful comments on the manuscript. We thank also two anonymous reviewers for very careful and constructive criticism to improve the quality of this manuscript. 


\section{References}

I. Laaksonen S, Kuusela J, Nikander S, Nylund M, Oksanen A: Parasitic peritonitis outbreak in reindeer (Rangifer tarandus tarandus) in Finland. Vet Rec 2007, 160:835-84I.

2. Laaksonen S, Solismaa M, Orro T, Kuusela J, Saari S, Kortet R, Nikander S, Oksanen A, Sukura A: Setaria tundra microfilariae in reindeer and other cervids in Finland. Parsitol Res 2008 in press.

3. Solismaa M, Laaksonen S, Nylund M, Pitkänen E, Airakorpi R, Oksanen A: Filarioid nematodes in cattle, sheep and horses in Finland. Acta Vet Scand 2008, 50:20.

4. Hoberg EP, Polley L, Jenkins EJ, Kutz SJ, Veitch AM, Elkin BT: Integrated approaches and empirical models for investigation of parasitic diseases in northern wildlife. Emerg Inf Dis 2008, 4:10-17.

5. Anderson RC: Nematode parasites of vertebrates; Their development and transmission. In The Superfamily Filarioidea 2nd edition. CABI Publishing. New York; 2000:467-529.

6. Prestwood AK, Pursglove SR: Prevalence and distribution of Setaria yehi in southeastern white-tailed deer. J Am Vet Med Assoc 1977, I 71 (9):933-935.

7. Innes JR, Shoho C: Cerebrospinal nematodiasis: focal encephalomyelomalacia of animals caused by nematodes (Setaria digitata); a disease which may occur in man. AMA Arch Neurol Psychiatry 1953, 70(3):325-349.

8. Hagiwara S, Suzuki M, Shirasaka S, Kurihara T: A survey of the vector mosquitos of Setaria digitata in Ibaraki Prefecture, central Japan. Jap J Sanit Zool 1992, 43:4. 29I-295

9. Nelson GS: Observations on the development of Setaria labiatopapillosa using new technique for infecting Aedes aegypti with this nematode. J Helminth 1962, 9:28I-296.

10. Wajihullah, Ansari JA: Larval development of Setaria cervi in the mosquito, Aedes aegypti. Helminthologia I98I, I8:267-27I.

II. Wajihullah : Comparative account of developing larvae of Setaria cervi and Diplotriaena tricuspis. J Vet parasitol 200I, I5: I I7-I20.

12. LeBrun RA, Dziem GM, Polovodova VP: Natural incidence of Setaria equina (Nematoda: Filarioidea) from Aedes canadensis (Diptera: Culicidae) in North America. J Med Entomol 1984, 2 I:472-473.

13. Shol' VA, Drobischenko NI: Development of Setaria cervi (Rudolphi, I 819) in Cervus elaphus maral. Helminthologia, Bratislava 1973, I 4:214-246.

14. Shol' VA, Drobishchenko NI: Development of the nematode Setaria cervi in the final host (maral deer). Problemy parazitologii. Trudy VII Nauchnoi Konferentsii Parazitologov USSR. Part II 1972:447-448.

I5. Chuvatina-Shmytova GYa, Khromova LA: The role of some Diptera as intermediate hosts of nematodes of domestic animals in the Mongolian People's Republic. Trudy Gel'mintologicheskoi Laboratorii (Ekologia i geografiya gel'mintov) 1974, 24:2II-220.

16. Anderson JR, Nilssen A: Do reindeer aggregate on snow patches to reduce harassment by parasitic flies or thermoregulate? Rangifer 2008, I 8:3-17.

17. Nelson CG: Factors influencing the development and behaviour of filarial nematodes in their arthropodan hosts. In Proceedings of the Second Symposium of the British Society for Parasitology Host-parasite Relationships in Invertebrate Hosts Edited by: Angela ER. Taylor: Blackwell Scientific publications; Oxford; 1964:74- I 19.

18. Zhong-Xing L, Li-rong Y: Morphological studies on the larval stages of three species of Setaria and Dirofilaria repens. Southeast Asian J Trop Med Public Health 1990, 2 I (I):95- 102.

19. Serrão ML, Labarthe N, Lourenco-de-Oliveira R: Vectorial competence of Aedes aegypti (Linnaeus I 762) Rio de Janeiro Strain, to Dirofilaria immitis (Leidy I856). Mem Inst Oswaldo Cruz 2001, 96(5):593-598.

20. Utrio P: Distribution of mosquitoes (Diptera, Culicidae) attracted by man in Finland in early July. Not Entomol 1978, 58: $107-\mid 14$.

21. Clements AN: The physiology of mosquitoes. Oxford: Pergamon Press; 1963.

22. Rehbinder C, Christensson D, Glatthard V: Parasitic granulomas in reindeer. A histopathological, parasitological and bacteriological study. Nord Vet Med I 975, 27( I 0):499-507.

23. Kadnikov VV: Protecting reindeer from insects as a way of preventing necrobacillosis. Veterinariya 1989, 8:27-26.
24. Bartholomay LC, Christensen BM: Vector-parasite interactions in mosquito-borne filariasis. In: World Class Parasites. The Filaria Kluwer Academic Publishers 2002, 5:9-19.

25. Dadaev S: Special features of the prevalence of the nematode Setaria labiatopapillosa in cattle in Uzbekista. Uzbekskii Biologicheskii Zhurnal 1984, 4:40-42.

26. Kumpula J, Colpaert A, Nieminen M: Suomen poronhoitoalueen kesälaidunvarat (In Finnish, English abstract: The summer pasture recourses of the Finnish reindeer managenment area). Kala-ja riistaraportteja no 152. Riistan ja kalantutkimus, Kaamanen 1999:54.

27. Lemke, et al.: . In Climate Change, 2007: The Physical Science Basis. Contribution of Working Group I to the Fourth Assessment Report of the Intergovermental Panel on Climate Change Edited by: Solomon S, et al. (Cambridge Univ. Press, Cambridge, 2007):377-383.

28. Clark TM, Hayes TK, Beyenbach KW: Dose-dependent effects of CRF-like diuretic peptide on transcellular and paracellular transport pathways. Am J Physiol 1998, 274(5 Pt 2):834-840.

29. Detinova T: Age-grouping methods in Diptera of medical importance with special reference to some vectors of malaria. Monogr Ser World Health Organ 1962, 47:13-191.

30. Bain O, Chabaud AG: Atlas de larves infestantes de Filaires. Trop Med Parasit 1986, 37:301-340.
Publish with Bio Med Central and every scientist can read your work free of charge

"BioMed Central will be the most significant development for disseminating the results of biomedical research in our lifetime. "

Sir Paul Nurse, Cancer Research UK

Your research papers will be:

- available free of charge to the entire biomedical community

- peer reviewed and published immediately upon acceptance

- cited in PubMed and archived on PubMed Central

- yours - you keep the copyright 